\title{
Inventory of Diversity Butterflies (Lepidoptera: Rhopalocera) in Sumber Clangap and Waduk Selorejo in East Java
}

Fariska Nur Ashari*, Nur Rizatul Addiniyah and Hayyin Nurul Aini

Biology Department, Universitas Islam Negeri Sunan Ampel, Surabaya, East Java, Indonesia

*Corresponding author: fariskanurashari4@gmail.com

\begin{abstract}
Diversity of butterflies in various habitats very diverse, and it is one of them in the region Sumber Clangap and Waduk Selorejo. It has seen from the combination of colors and which wing shape varies. In this, both regions were chosen because it had been affected by Mount Kelud eruption, which causes damage to the surrounding area. The purpose of this research is to know the diversity of butterflies (Lepidoptera: Rhopalocera) in the region of Sumber Clangap and Waduk Selorejo, East Java. This research was conducted on 26-29 January 2019. Sampling has taken by the method of Belt transect along the transect path randomly with a technique snapshot experiment and a sweeping technique. Based on the observations obtained 3 of the same family, Nymphalidae, Pieridae, and Papillionidae. The butterfly diversity in Waduk Selorejo belongs to low, whereas in Sumber Clangap are classified by index ShannonWinner $=0.38 \mathrm{H}^{\prime}$ and $\mathrm{H}^{\prime}=2.47$. Found eight types of butterflies from 3 families with a total of 13 species and has a value of $\mathrm{H}^{\prime}=2.47$.
\end{abstract}

Keywords: Diversity; Lepidoptera; Waduk Selorejo; and Sumber Clangap.

\section{Introduction}

Kelud is one of the most active volcanoes in Indonesia, which is located between the district of Blitar, Blitar City, Kediri District, Kediri City, and District of Malang. Since the year $1000 \mathrm{M}$, Kelud has erupted more than 30 times, with the most massive eruption of magnitude 5 Volcanic Explosivity Index (VEI). Entering the 21st century, there have been two eruptions, that is in 2007 and 2014 years. The 2014 eruption of Kelud is considered more powerful than in 1990. The volcanic ash caused by the eruption of Mount Kelud spread up to $17 \mathrm{~km}$. The area in East Java affected by volcanic ash such as Kediri and Malang (Achmad and Hadi, 2015; Rahmadana, 2014).

Waduk Selorejo is one of the reservoirs located in Malang district at an altitude of 625 masl. This reservoir is used as flood control, irrigation, hydroelectric power plant, fisheries and tourism (Suryanto, 2011). Around the dams can be found several species of plants, both natural and artificial (planted). Waduk Selorejo is now being developed into tourist attractions. The region can be found plants and wild plants around the reservoir. A wild plant that position is not far from the dam has excellent to do observations of butterflies because there were encountered butterflies passing by. Sumber Clangap is the main water source located in the village Puncu, sub-District Puncu, Kediri. The source is utilized for residents to meet water needs. Water from these sources flowed into several villages in the district of the town including Puncu, Asmorobangun, Satak, and Kampung Baru. Around this place can be found in the forest to be protected by the 
government. However, in 2014, the region affected by the eruption of Mount Kelud, so some habitat is a loss (Abdillah, 2018).

Water draining Sumber Clangap comes from a waterfall under Kelud. The flow of the river that forms Clangap Source. Water passing through the forest and then accommodated called Cekdam Jedingmiring. During the dry season, the river is inactive and active again during the rainy season (Abdillah, 2018). Both of these areas are affected by the eruption of Mount Kelud. Therefore, the volcano a significant impact on a wide range of damage, including a variety of vegetation due to soil's condition as a growing medium a change in chemistry, physics, and biology, thereby inhibiting plant growth is not optimal. The butterfly is one bioindicator used to determine the condition of habitats, because if there are diverse species of butterflies then variegated vegetation these plants in a habitat. In essence, the butterfly is very dependent on the host plant diversity, to provide a relationship between the diversity of butterfly habitat conditions. The decline in butterfly species can occur due to changes in forest functions, water pollution and air (Saputro, 2007).

Butterflies are insects that are included in the order Lepidoptera, meaning insects that almost the entire body surface covered by sheets of scales that give style and color of butterfly wings (Scoble, 1995). Butterflies are insects of the most widely known and frequently encountered because of the shape and color are beautiful and varied, and are generally active during the day (diurnal) that are classified into suborder Rhopalocera. Butterflies are very dependent on their hosts. If the host is still prevalent that butterfly populations are still high. So far, the impact of the eruption of Mount Kelud occurred in 2014, which affects Waduk Selorejo, and Sumber Clangap has been widely studied from the field of water (Abdillah, 2018) and soil (Achmad and Hadi, 2015). But for Rhopalocera, suborder observation has not been done. The purpose of this study was to determine the species diversity of butterflies (Lepidoptera; Rhopalocera) in Waduk Selorejo and Sumber Clangap, East Java affected by the eruption of Mount Kelud.

\section{Materials and Methods}

The research was conducted on January 26-29, 2019. The research sites were Waduk Selorejo, Sambirejo Hamlet, Pandansari Village, Ngantang Sub-District, Malang Regency, and Sumber Clangap, Puncu Village, Puncu District, Kediri Regency. The tools used in this study were sweep net, thermohygrometer and stationery.

This study uses the Belt Transect method, data retrieval is using the snapshot experiment method. The Belt Transect method, roaming, follow the current path. Observations in the Waduk Selorejo begin from the motorbike parking lot to the vicinity of the reservoir. Whereas the observations at Sumber Clangap started from after the reservoir of water near the community plantations, then followed the current path (the road that had been made by the residents) until it was blocked by Clangap (Cekdam Jedingmiring). Snapshot experiment retrieval that is data retrieval is only done once 
without repetition. The process of identifies butterflies based on the color of the wings both forewing and hindwing. Analysis of the data discussed is the use of species diversity index Shannon-Wiener (Syahputra, 2015) as follows:

$$
H=-\sum(n i / N) \ln (n i / N)
$$

$\mathrm{H} \quad$ : Index diversity

ni : Number of individual types

$\mathrm{N} \quad$ : Total number of individuals

\section{Results and Discussion}

The research has been carried out in the Waduk Selorejo, Malang regency, and Sumber Clangap, Kediri Regency, using the Belt Transect method. It was found 68 individuals of the 22 species consisting of 5 genera. The results obtained can be seen in Table 1.

Table 1. Data types of butterflies in Selorejo Reservoir and Source Clangap

\begin{tabular}{|c|c|c|c|}
\hline Locations & Family & Species & Total \\
\hline \multirow{18}{*}{ Sumber Clangap } & \multirow{3}{*}{ Pieridae } & Eurema sp. & 1 \\
\hline & & Catopsilia pomona & 6 \\
\hline & & Ypthima sp. & 12 \\
\hline & \multirow{7}{*}{ Nymphalidae } & Neptis hylas & 7 \\
\hline & & Mycalesis sp. & 2 \\
\hline & & Euploea mulciber & 2 \\
\hline & & Tirumala septentrionis & 2 \\
\hline & & Pareronia valeria & 1 \\
\hline & & Ideopsis vulgaris & 2 \\
\hline & & Papillio memnon & 3 \\
\hline & \multirow{3}{*}{ Papillionidae } & Troides helena & 8 \\
\hline & & Pachliopta aristolochiae & 1 \\
\hline & & Graphium doson & 1 \\
\hline & \multirow[t]{2}{*}{ Hesperidae } & Tellicota augias & 1 \\
\hline & & Hypolycaena sp. & 1 \\
\hline & \multirow[t]{3}{*}{ Lycaenidae } & Zizula hylax & 5 \\
\hline & & Elymnas hypermnestra & 2 \\
\hline & & Appias olferna & 2 \\
\hline \multirow{7}{*}{ Waduk Selorejo } & \multirow[t]{3}{*}{ Pieridae } & Eurema sp. & 3 \\
\hline & & Catopsilia pomona & 1 \\
\hline & & Junonia atlites & 1 \\
\hline & \multirow[t]{2}{*}{ Nymphalidae } & Junonia almana & 2 \\
\hline & & Danaus sp. & 1 \\
\hline & \multirow{3}{*}{ Papillionidae } & Papillio memnon & 2 \\
\hline & & Graphium agamemnon & 1 \\
\hline Total Individuals & & & 68 \\
\hline
\end{tabular}

Based on the results obtained in both regions, the value of diversity index with formula Shannon-Winner is obtained as much as 2,47 in Sumber Clangap area and 0,38 
in the Waduk Selorejo area. Thus, the level of diversity in the Sumber Clangap area is classified as moderate, or the distribution of individual numbers of each species and the stability of the community is moderate. While in the Waduk Selorejo area is classified as low or uneven distribution in each species found, there are only eight species. This is caused by abiotic factors, including temperature and humidity; also, the biotic factor is existing the host plants of butterfly (Fauziah et al., 2017).

Observations in the Waduk Selorejo were carried-out during the day around $13.00-15.00$ WIB with a temperature range of $25,9^{\circ} \mathrm{C}$ and humidity of $82 \%$ at an altitude of 600 meters and also supported by cloudy weather. According to Amir et al. (2002), butterflies activity on moderate air humidity of around $60 \%$ and warm temperature around $30^{\circ} \mathrm{C}$ and enough sunlight. This causes no heat from the sun to penetrate the plains so that butterflies prefer to take shelter or hide under the leaves. While in Waduk Selorejo. Butterflies are easily found in areas that quite open because trees do not block sunlight. Sunlight is essential for butterflies because butterflies are cold-blooded animals. Sunlight can provide heat energy to the body of the butterfly so that body temperature will rise and metabolism will be faster (Natasa, et al., 2016)

The range of humidity and temperature measurement results in these two places are still within the scale needed for survival, such as used reduced evaporation of body fluids. The range of humidity is about $64-94 \%$ and $30-35^{\circ} 9 \mathrm{C}$ (Achmad, 2002), and the entire family found is Papilionidae, Nymphalidae, Peridae, Lycanidae, dan Hesperidae and the both of the two places dominating is Family Nymphalidae. Nymphalidae have color characteristics that are dominated by gray, black, brown, with white hues, and some large species have bright colors, for example, Hipolymnas bolina, but some have medium body shapes too. Nymphalidae can be found around bushes and trees and has a high intensity of flying. This family abundance is inseparable from the factor of the availability host plant of butterflies, either the food plant. Some plants to feed Nymphalidae larvae are Araceae, Musaceae, dan Peacea (Peggie and Amier, 2006).

The least family was found in Hesperidae because of availability of plants and changing climate or weather in every place. Hesperidae is usually doing activity in a dimly lit condition (crepuscular) that's why these families often misunderstood if he belongs to the group of moth or Heterocera (Peggie and Amier, 2006). From this observation, in Sumber Clangap still found Troides helena, this species was rare and protected. Troides helena is one of a butterfly with large and beautiful wings so that it can attract the collectors to be traded. Therefore, the government issued Permen LHK No. 92 2018, stating that all species from Troides in the list Appendix II CITES to protect the extinction of this type of butterfly (Nurjannah, 2010).

Other than that, due to the availability of host plant forest betel (Aristolocia spp.) are not supported. These plants also become a hostplant for the different species of butterflies, especially the family of Papilionidae. One of them is Pachliopta aristolochiae, this species was found in the same place. If the forest betel plant already has eggs from these two butterflies, the caterpillar will eat up all the leaves and even cut the stems. It is 
thus causing this plant to die before it can bear fruit or regenerate other parts (Aprillia, et al., 2018). Besides being pollinator, butterflies also function as bioindicators of environmental quality because butterflies are very susceptible to environmental changes (Kairupan, et al., 2015).

As volcanic eruption Kelud mounts in 2014, which affected this area, soil conditions were very influential in the survival of plants and animals that lived in the vicinity. Soil conditions after being exposed to volcanic ash in a long time will have a positive and negative impact. The negative effect is caused by the large amount of volcanic material that hides the soil surface so that it can change soil conditions as a growing medium. And the positive impact is it can add nutrients needed by the soil as an addition to mineral spare parts and enrich the chemical composition and improve physical properties that are poor in nutrients or soil that has further weathering (Sediyarso and Suping,1987). Volcanic ash has contained a mineral that needed by the soil, and plants with the highest element composition are $\mathrm{Ca}, \mathrm{Na}, \mathrm{K}, \mathrm{Mg}$, and also macronutrients like $\mathrm{P}$ and $\mathrm{S}$, while the micronutrients are $\mathrm{Fe}, \mathrm{Mn}, \mathrm{Zn}, \mathrm{Cu}$ (Anda and Wahdini, 2010). It can be concluded that the abundance of butterflies obtained is strongly influenced by the diversity of host plants originating from fertile soil due to volcanic materials buried.

\section{CONCLUSION}

From the results of the research, it can be concluded that the butterfly species at Sumber Clangap are categorized as moderate according to the results of the diversity index ( $\left.\mathrm{H}^{\prime}\right)$ is 2.47 while the Waduk Selorejo is classified as low with ( $\left.\mathrm{H}^{\prime}\right)$ is 0.38 . This is due to environmental factors, temperature, and host plants. The discovery of Troides helena at the Sumber Clangap indicates that there are still host plants from the butterfly. This could be due to volcanic ash from the Kelud eruption containing minerals needed by soil and plants so that the plants thrive again in a certain period after the explosion.

\section{References}

Abdillah, Muhibbuddin, M. (2018). Odonata diversity and its role as an indicator of water quality at the source and the source Mangli village Clangap Puncu Puncu District of Kediri. Essay. Surabaya: Faculty of Science and Technology, the State Islamic University Sunan Ampel.

Achmad, A. (2002). Potential and Distribution of Butterflies in Nature Park Region Bantimurung. In: Workshop on Management of Community-Based Butterflies. Batimurung.

Achmad, SR, and Hadi, H. (2015). Identification of Chemical Properties Volcanic Ash and The Recovery Effort Rubber Plant Affected eruption of Mount Kelud (Case Study: Gardens Ngrangkah Pawon, East Java). News perkaretan, 34 (1), 19-30. 
Anda, M., and W. Wahdini. (2010). Nature, mineral composition, and the content of the various elements in the ash eruption of Merapi, October-November 2010. Bogor: Center for Research and Development of Land Resources.

Aprilia, I., Yustian, I., Setiawan, A., and Doni, S. (2018). Diversity of Butterflies (Lepidoptera: Rhopalocera) in the Gunung Raya Wildlife Reserve, Sub District Warkuk Ranau, South Sumatra. Biological Research Journal, 4 (2), 2477-1392.

Fauziyah, S., Fitrahyanti, FM, Astri, DW, Themas F., Eka KP, Dwi, W., and Thobib, H., (2017). Diversity of butterflies in the conservation area Petungsewu Wildlife Education Center, Malang, East Java. Sem Pros Nas mobi Biodiv Indon, 3 (2), 252257.

Kairupan, CF, Koneri, R., and Trina, ET (2015). Genetic variation Troides helena (Lepidoptera: Papilionidae) Based on COI gene (cytochrome C Oxydase I). Unsrat Journal of Mathematics and Natural Sciences. 4 (2), 141-147.

Natasa, IW, Zahida, F., and Yuda, P. (2016). Diversity of the Butterflies (Lepidoptera) In Plawangan Region Mount Merapi National Park, Yogyakarta. BL01065 Journal.

Nurjannah, ST (2010). Biology Troides Helena Troides helena helena and Hephaestus (Papilionidae) in Captivity. Thesis. Bogor Agricultural University in Bogor.

Peggie, D., and Amier, M. (2006). Practical Guide to Butterflies in the Garden. Bogor: Center for Biology LIPI.

Saputro, NA (2007). Butterfly Species Diversity on Campus IPB. Essay. Bogor Agricultural University in Bogor.

Sediyarso, M., and S. Suping. (1987). Abu Galunggung influence on Agricultural Land. Bogor: Land Research Center.

Suryanto, Maizar, A. (2011). Abundance and composition of phytoplankton in the reservoir Selorejo Ngantang Malang. Maritime Journal, 4 (2), 34-39.

Syahputra M (2015) Measurement of Diversity butterflies (Lepidoptera by using Method: Time Search. Media Development Scientific. 9 (4): 68-72. 